УДК $1(510)+294.3(510)$

DOI: 10.18101/1994-0866-2020-2-37-45

\title{
О ВЛИЯНИИ БУДДИЗМА НА ПОЛИТИЧЕСКУЮ СТРУКТУРУ КИТАЙСКОГО ОБЩЕСТВА ЭПОХИ ТАН
}

\author{
(C) Мазур Татьяна Геннадьевна \\ кандидат философских наук, доцент, \\ Институт монголоведения, буддологии и тибетологии Сибирского отделения \\ Российской академии наук \\ Россия, 670047, г. Улан-Удэ, ул. Сахьяновой, 6 \\ E-mail: mtbi@yandex.ru
}

В работе рассматривается вопрос о влиянии буддизма на политическую структуру китайского общества в эпоху Тан (618-907). На основе институционального и субстанционального подходов к социальной структуре общества выделены основные элементы политической структуры: политические институты (институт главы государства, институт исполнительной власти, институт государственной службы, институт права) и социально-политические группы (император, привилегированные сословия, непривилегированное сословие) танского общества, проанализировано влияние на них буддизма. Показано, что влияние буддизма на политическую структуру в эпоху Тан было незначительным. Буддизм не оказал существенного влияния на политические институты китайского общества, его появление не привело к образованию новой социально-политической группы и нового субъекта права в политикоправовых отношениях. В политической структуре танского общества буддизм существовал в традиционных для Китая социально-политических группах, представители которых являлись носителями его идей.

Ключевые слова: буддизм; религия; эпоха Тан; общество; политическая структура; политический институт; институт главы государства; институт исполнительной власти; институт государственной службы; институт права; социально-политическая группа.

\section{Для цитирования}

Мазур T. Г. О влиянии буддизма на политическую структуру китайского общества эпохи Тан // Вестник Бурятского государственного университета. Философия.

2020. Вып. 2. С. 37-45.

В отечественном китаеведении эпоха Тан (618-907) считается «золотым веком» китайского буддизма, периодом его наивысшего расцвета $[1 ; 2 ; 3]$. В этот период большое развитие получает буддийское искусство, философия, религиозная догматика и практика, возрастает роль буддизма в экономической, политической, социальной и культурной жизни страны [2, с. 25]. Говоря о влиянии буддизма на танское общество, в том числе на его политическую сферу, исследователи отмечают, что буддизм в этот период широко использовался императорами как дополнительное средство управления государством и обоснования легитимности своих притязаний на верховную власть [2, с. $29 ; 4$, с. $43 ; 5$, с. $129 ; 6$, с. 30], вызывал интерес у представителей служилого сословия [7] и т. д.

Эпоха Тан не раз становилась предметом специального исследования, в том числе в контексте вопроса о распространении буддизма в Китае [4-17]. В то же 
T. Г. Мазур. О влиянии буддизма на политическую структуру китайского общества эпохи Тан

время анализ отдельных сфер танского общества с целью выявления степени влияния буддизма на их структурные элементы не предпринимался. Подобное исследование представляется актуальным в силу того, что позволяет наглядно продемонстрировать, какие сферы общества подверглись влиянию буддизма в большей степени, а какие - в меньшей, что способствует более глубокому пониманию процесса адаптации буддизма в Китае, его места и роли в китайской культуре.

В данной работе проанализируем, в какой мере буддизм оказал влияние на политическую структуру китайского общества в эпоху Тан. Исходя из институционального и субстанционального подходов к социальной структуре общества, в качестве основных элементов политической структуры будем рассматривать политические институты и социально-политические группы.

Основные политические институты китайского общества были сформированы уже в эпоху Хань (206 до н. э. - 220 н. э.). Среди таковых необходимо выделить, прежде всего, институт главы государства, институт исполнительной власти, институт государственной службы и институт права.

Институт главы государства уходит корнями в протогосударственное образование Шан-Инь (XVI-XI вв. до н. э.), когда местом сосредоточения центрального аппарата власти становится ставка вана, считавшегося «главным среди живущих потомков всех умерших правителей» [18, с. 126-129]. Идеологическое обоснование права шанских ванов на власть обеспечивалось посредством культа Шан-ди первопредка Шан-иньского рода и верховного божества [19, с. 31]. Свое дальнейшее развитие институт главы государства получает в следующую эпоху - Западная Чжоу (XI-VIII вв. до н.э.), когда чжоусцы, захватив власть, идентифицировали личностно-иньского Шан-ди с местом его пребывания и выдвинули на передний план Небо как высшую абстрактную божественную силу, приписав именно ему верховное право распоряжаться делами на земле [18, с. 160]. Так, чжоуские ваны стали сынами Неба (Тянь цзы), а вся подвластная им территория - Поднебесной (Тянься) [19, с. 37]. Важным моментом в процессе институциализации верховной власти стала концепция «мандата Неба» (тянь мин), автором которой считается самый мудрый и известный из первых чжоуских правителей Чжоу-гун [18, с. 161]. Согласно ей, Небо могло лишить мандата на управление утратившего добродетель (дэ) правителя и передать его более достойному, что решило проблему обоснования преемственности власти и ее легитимации [18, с. 163]. Следующий шаг в становлении института главы государства в Древнем Китае был сделан Конфуцием, который усилил позиции государя за счет введения в систему государственного управления принципа «сыновней почтительности» (сяо). Согласно ему, государь является отцом для своих подданных, которые должны стремиться служить ему, а само государство должно строиться по образцу семейных отношений [19, с. 71]. В эпоху Хань Дун Чшуншу систематизировал все эти аспекты государственного управления и институт главы государства обрел свой классический вид. Порядок наделения главы государства полномочиями в этой системе основывался на том, что государственная власть имеет сакральный характер, является продолжением созидательной силы Неба [19, с. 76], и, будучи «сыном Неба», государь имеет право управлять Поднебесной. Однако выполнение государем обязанностей находится под постоянным контролем Неба, и Небо способно лишить государя, утра- 
тившего свою добродетель, «мандата» на управление. Это положение легло в основу порядка прекращения полномочий главы государства. Что касается функций главы государства и вытекающих из них полномочий, то, как отец для своих подданных, император обладает верховной духовной, законодательной, судебной, исполнительной и военной властью. Являясь верховным жрецом, император осуществляет общение с Небом, совершает обряды, приносит жертвы в его честь, то есть выполняет роль посредника между Небом и обществом, и для сохранения этого статуса он обязан воплощать в себе наиболее ценные человеческие качества $[11$, c. $56 ; 20$, с. $111 ; 17$, с. 212].

В эпоху Тан порядок наделения полномочиями главы государства был таким же, как и в предшествующие периоды. Так, в «Ди фань» («Правила императоров»), политическом завещании Тай-цзуна (627-649), второго императора династии Тан, в полном соответствии с традицией говорится о божественном происхождении власти императора $[11$, с. 63]. Неизменными в рассматриваемую эпоху остаются и представления о «мандате Неба» и благой силе $\partial э$, которой должен был обладать претендент на управление Поднебесной. Так, в своем завещании Тай-цзун утверждает, что его предшественник Гао-цзу, основатель династии Тан, обладал чудесными талантами подобно совершенным правителям древности, поэтому и обрел по воле Неба право основать династию [11, с. 63]. Порядок прекращения полномочий главы государства в Танскую эпоху также не отличался от предшествующей традиции. Так, Гао-цзу, как отмечается в завещании, не смог добиться полного порядка и гармонии в Поднебесной, обладая недостаточной устроительной силой $\partial э$, и, как следствие, право на управление государством перешло к Тайцзуну $[11$, с. 64]. Неизменными остались и функции главы государства. В эпоху Тан император считался сыном Неба, в руках которого сосредотачивалась вся верховная власть, и одновременно отцом своих подданных [6, с. 30]. В своем завещании Тай-цзун изображает императора «высшим творцом и арбитром социального и политического порядка», стремится передать идею всеобъемлемости его функций и задач, сведя их в две большие группы: социальные и космологические [11, c. 65].

Таким образом, правовой статус главы государства в Танскую эпоху не претерпевает заметных изменений. Тем не менее в нем можно выделить ряд моментов, в которых китайская традиция все же столкнулась с влиянием буддизма.

Во-первых, это известный в истории Китая спор о том, должен ли монах быть почтительным к императору. Эта полемика между буддийскими монахами и официальной властью, суть которой состояла в том, обязан ли монах наравне с другими подданными оказывать императору знаки почтения, вспыхнула еще в начале IV в., однако точка в ней была поставлена в эпоху Тан, когда буддийским монахам вменилось в обязанность почтительное отношение к императору $[21 ; 22$, с. 86]. Этот спор содержал в себе угрозу традиционным китайским политическим институтам, так как в своей основе касался не только места монаха в обществе, но места в нем самого императора. Как справедливо отмечает Т. Г. Комиссарова, «спор шел о том, останется ли сакральное обоснование власти китайского императора $<\ldots>$ прерогативой императора, или он должен будет разделить его с буддийскими священниками» [21, с. 49]. Как было сказано выше, в китайской традиции император представал как «сосредоточие космических сил, фокус мирового круговорота», он 
T. Г. Мазур. О влиянии буддизма на политическую структуру китайского общества эпохи Тан

был посредником между миром небесным и земным, Сыном Неба, и его власть была неделима и не допускала противодействия [23, с. 105-106]. В буддийской концепции верховной власти монарх - это бодхисатва, чаккаватин, так же как и в Китае, самый достойный в моральном плане, но находящийся под постоянным контролем сангхи как хранителя и толкователя морально-нравственных законов [24, с. 129]. В императорском же Китае верховная власть, как указывалось выше, находилась лишь под контролем Неба, и только оно следило за тем, чтобы император сохранял добродетель, и только оно - никто из живущих на земле - могло лишить императора «мандата на управление». Таким образом, спор о том, должен ли монах быть почтительным к императору, затрагивал основы традиционного для Китая института главы государства, так как право монахов не оказывать почести императору ставило сангху не просто на один уровень с императором, а в моральном плане — выше императорской власти.

Во-вторых, буддизм в эпоху Тан все-таки затронул своим влиянием функции императора. Можно констатировать тот факт, что в эту эпоху их перечень расширился и к перечисленным выше добавилась еще одна - функция накопления «духовных заслуг» (гун дэ). Одной из форм проявления этой функции стало, как известно, строительство буддийских храмов, которое рассматривалось как накопление «духовных заслуг» и отдельным монархом, и династией в целом, то есть носило государственно-религиозный характер [14, с. 105-107].

Что касается института исполнительной власти как механизма управления государственными делами, то он в Танскую эпоху не претерпел изменений, связанных с влиянием буддизма. Как отмечает Ю. Н. Полохало, система государственного устройства и бюрократический аппарат в этот период складывались исходя из опыта, накопленного в древности [17, с. 211]. Структура исполнительной власти при династии Тан имела следующий вид. Ближайшими помощниками императора были два канцлера-советника, управление страной осуществлялось через три палаты: Совет Двора и Государственную канцелярию (законодательная власть), а также Кабинет министров (исполнительная власть) [17, с. 212]. Непосредственно исполнительная функция реализовывалась через шесть ведомств: ведомство ритуала, ведомство чинов, ведомство финансов, военное ведомство, ведомство наказаний, ведомство общественных работ. На уровне провинций были свои чиновные управы во главе с наместником-губернатором, при этом, помимо уездных, все чиновники назначались из центра и им же контролировались, что было важной особенностью централизованной административно-бюрократической системы Китая [17, с. 213].

Институт государственной службы в традиционном Китае - это исторически сложившаяся форма организации деятельности служилого сословия (uu) социальной группы гражданских государственных служащих. Социальная группа ши выходит на передний план в эпоху Восточная Чжоу (VIII-III вв. до н. э.) как замена родовой аристократии в деле управления государством. Уже тогда закладывается одна из важнейших особенностей этой группы и института государственной службы: обязанность представителей этого сословия состоять на службе у государя для сохранения своего привилегированного статуса. Как подчеркивает С. В. Волков, это сословие являлось именно сословием служащих, в отличие, 
например, от европейского дворянства — по большей части сословия людей, имеющих право служить [25, с. 204]. Большой вклад в становление института государственной службы в традиционном Китае был сделан Конфуцием, который выдвинул идеологическое обоснование права служилых-ши на власть, превратив силу дэ из благодати, ниспосылаемой Небом правителю, в принадлежность преобразованного и обученного человека - «благородного мужа» (изюньизы) - в меру внутреннего этического совершенства [26, с. 50-52]. В результате важной особенностью института государственной службы в Китае стала идея неразрывной связи мудрого правителя с достойным помощником. Аппарат служилого сословия превратился в административную опору власти, был обязан реализовывать политику государя $[19$, с. $75-76]$ и обеспечивал целостность и незыблемость самой политической системы. Еще одной важной составляющей института государственной службы в традиционном Китае стала система отбора на службу. Уже в эпоху Чжаньго (V-III вв. до н. э.) зародилась идея о том, что на государственную службу следует отбирать не по знатности происхождения, а посредством экзаменационных испытаний [23, с. 124]. Подобный метод отбора чиновников на протяжении длительного времени совершенствовался, функционировал наряду с другими методами и в эпоху Тан стал важным каналом отбора чиновников, превратившись впоследствии в неотъемлемую часть традиционного Китая [23, с. 124125].

Все отмеченные особенности института государственной службы — обязательность службы для сохранения привилегированного статуса, место посредника между мудрым правителем и народом и, как следствие, «охранника» существующих политических отношений, экзаменационная система как способ комплектования группы государственных служащих - мы находим и в Танскую эпоху. Так, биография Хань Юя (768-824), типичного чиновника-конфуцианца эпохи Тан, свидетельствует нам о его неоднократных попытках сдать экзамены для получения чиновничьей должности [5, с. 27-29], а его произведения - о стремлении служить государю и следить за соблюдением правильных устоев в государстве [27].

Институт права в Китае начал формироваться во второй половине первого тысячелетия до нашей эры $[28$, с. 3]. В эпоху Тан он получил свое дальнейшее развитие, что привело к появлению кодекса династии Тан - «Тан люй шу и», которым, как считает исследователь средневекового китайского права В. М. Рыбаков, завершился процесс конфуцианизации права, начавшийся в период Хань [12, c. 16]. В то же время В. М. Рыбаков допускает отдельные заимствования из буддийской религии в китайском праве, отмечая, что такой важный элемент кодекса «Тан люй шу и», как список десяти зол, в который были сведены преступления, считавшиеся наиболее опасными, оформился, по-видимому, не без воздействия буддизма и его десяти зол [12, с. 41]. Однако между этими двумя списками, на наш взгляд, нет никаких параллелей. Они различны и по своему содержанию, и по своей сути. В буддизме десять зол (десять (черных) грехов): 1) умертвление живого; 2) воровство, грабеж; 3) разврат; 4) ложные речи; 5) двусмыслие (лицемерие); 6) ругательства; 7) велеречивая речь (превратные слова и речи); 8) желания и страсти; 9) гнев и раздражение; 10) видение зла (исправление кармы, вера в возможность счастья) [2, с. 55-56]. К числу «десяти зол» в китайском праве относились: 1) заговор о мятеже против государя (моу фань); 2) великое непокорство, 
T. Г. Мазур. О влиянии буддизма на политическую структуру китайского общества эпохи Тан

бунт (моу да фань); 3) заговор, измена (моу пань) (измена императору, переход на сторону чужеземного государства); 4) неподчинение, непокорство (э ни) (преступления против кровных родственников); 5) преступления, противоречащие естественному порядку вещей (бу дао) (особо тяжкие преступления: убийство в одной семье трех человек, особо жестокие убийства посредством расчленения жертвы или ее трупа и т. п.); 6) выражение великого непочтения (да бу изинь) (группа преступлений, направленных против ли, действующих социальных норм); 7) выражение сыновней непочтительности, непочтения к родителям (бу сяо); 8) несогласие, разногласие (бу му) (умысел убить или продать родственника, донос женой на мужа, донос на старшего родственника и т. д.); 9) несправедливость, неправедность (бу u) (преступления, совершенные друг против друга лицами, не состоявшими в кровном родстве, но связанными социальными нормами ли); 10) кровосмесительные половые связи (нэйлуань) [28, с. 46-49]. Из приведенных списков видно, что в буддизме десять зол (десять грехов) касаются жизни и поведения отдельного человека, затрагивают, главным образом, моральный аспект, в китайском праве десять зол относятся ко всему обществу, охватывая моральный, социальный и политический аспекты. В буддизме десять зол - это поступки, которые не позволяют отдельному человеку достичь гармонии как основы для последующих более высоких духовных практик. В китайском праве - это преступные деяния, которые разрушают установленный социальный порядок [28, с. 46].

Таким образом, все основные политические институты танского общества институт главы государства, институт исполнительной власти, институт государственной службы и институт права - оказались практически не затронутыми влиянием буддизма, в своей основе оставались традиционно китайскими.

Если рассмотреть танское общество с точки зрения субстанционального подхода, то основными социальными группами-участниками политических отношений будут следующие: 1) император, находящийся на самой вершине политической пирамиды, в определенном смысле над обществом, между Небом и Землей;

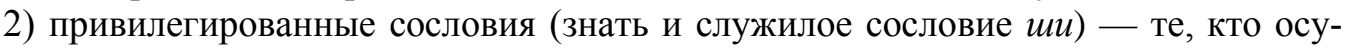
ществляет политическое управление; 3) непривилегированное сословие (свободные общинники, бесправные несвободные люди (рабы), неполноправное сословие свободных, занимавших промежуточное положение между ними) - те, на кого распространяется политическое управление.

Необходимо отметить, что появление буддистов в Китае не привело к созданию ими социальной группы, играющей сколько-нибудь значимую роль в политической сфере. В социальном пространстве танского общества буддизм был представлен малыми группами - буддийскими общинами, относящимися к различным школам буддизма. Не являлись буддисты и самостоятельным субъектом права, хотя в китайском языке к эпохе Тан уже существовали специальные термины для обозначения категории буддийских монахов и монахинь - сэн и ни (в отличие, например, от даосских - даоши и нюйгуань). В кодексе «Тан люй шу и» буддийские монахи были неотделимы от даосских монахов: «Всякий раз, когда указывается на даосских монахов и монахинь, буддийские монахи и монахини равно [имеются в виду]», - указывается в кодексе [12, с. 286]. Даже объединив буддийских монахов с даосскими в одну группу, Танский кодекс не предлагает им систему наказаний, учитывающую их статус, хотя традиционно согласно кодексам 
законов «при судебных разбирательствах преступлений и вынесении приговоров надлежало строго учитывать сословный, ранговый, семейно-родственный и возрастной статусы как обвиняемых, так и потерпевших» [29, с. 305]. Буддийская сангха, таким образом, фактически никак не выделялась в качестве отдельной группы в политико-правовых отношениях в танском Китае.

Не приведя к образованию большой социальной группы в политическом пространстве Китая эпохи Тан, буддизм существовал в мировоззрении представителей всех социально-политических групп, но преимущественно на уровне массового сознания, не оказывая влияния на политику государства. Так, буддизм вызывал глубокий интерес у представителей служилого сословия — основной социально-политической группы китайского общества, однако затрагивал своим влиянием лишь чувственный, эмоциональный уровень их сознания, т. е. уровень общественной психологии, в то время как идеологический уровень сознания этой группы был занят конфуцианством как сословной идеологией [27]. На этом же общественно-психологическом уровне буддизм существовал и в среде представителей непривилегированного сословия. Однако буддизм в этот период проникал и на уровень специализированного сознания - уровень политической идеологии благодаря тому, что императоры Танской династии нередко включали его положения в официальную идеологию государства.

Итак, несмотря на то, что буддизм действительно оказывал большое влияние на китайское общество в эпоху Тан, это влияние было неравномерным. Политическая структура танского общества осталась практически не затронутой буддизмом. Буддизм не смог оказать существенного влияния на политические институты танского общества. Появление буддизма в Китае не привело к образованию новой социально-политической группы и нового субъекта права в политико-правовых отношениях в эпоху Тан. Не внеся изменений в политическую структуру танского общества, буддизм существовал в традиционных для Китая социально-политических группах, представители которых являлись носителями его идей.

Работа выполнена в рамках государственного задания (проект XII.191.1.3. «Комплексное исследование религиозно-философрских, историко-культурных, социально-политических аспектов буддизма в традиционных и современных контекстах России и стран Центральной и Восточной Азии», № AAAA-A17117021310263-7).

Лuтература

1. Васильев Л. С. История религий Востока. М.: Университет, 2000.

2. Янгутов Л. Е. Китайский буддизм: тексты, исследования, словарь. Улан-Удэ: Издво Бурят. гос. ун-та, 1998. 160 с.

3. Чебунин А. В. История проникновения и становления буддизма в Китае. Улан-Удэ: ИПК ВСГАКИ, 2009. $278 \mathrm{c}$.

4. Adshead S. A. M. T'ang China: The Rise of the East in World History. N. Y.: Palgrave Macmillan, 2004. $233 \mathrm{p}$.

5. Hartman Ch. Han Yü and the T'ang Search for Unity. Princeton: Princeton University Press, 1986. 460 p. 
T. Г. Мазур. О влиянии буддизма на политическую структуру китайского общества эпохи Тан

6. Халтаева О. Р. Буддизм и конфуцианство в политической практике танского Китая // Вестник Бурятского государственного университета. Педагогика. Филология. Философия. 2015. № 6а. С. 29-32.

7. Мазур Т. Г. Хань Юй и буддизм (к вопросу об индивидуальном уровне существования религии в обществе) // Буддологические исследования: религиоведческий альманах. 2019. Вып. 2. С. 84-90.

8. Weinstein S. Buddhism under the T'ang. N. Y.: Cambridge University Press, 1987. 256 p.

9. Шефер Э. Золотые персики Самарканда. Книга о чужеземных диковинках в империи Тан. М.: Наука, 1981. 608 с.

10. Крюков М. В., Малявин В. В., Софронов М. В. Китайский этнос в средние века (VII-XII вв.). М.: Наука, 1984. 336 с.

11. Попова И. Ф. Политическая практика и идеология раннетанского Китая М.: Восточная литература, 1999. 279 с.

12. Уголовные установления Тан с разъяснениями (Тан люй шу и). Цзюани 1-8 / введ., пер. с кит. и коммент. В. М. Рыбакова. СПб.: Петербургское Востоковедение, 1999. 384 с.

13. Кычанов Е. И. Государственный контроль за деятельностью буддийских общин в Китае в период Тан-Сун (VII-XIII вв.) // Буддизм и государство на Дальнем Востоке. М.: Наука, 1987. С. 71-90.

14. Мартынов А. С. Буддизм и двор в начале династии Тан (VII-VIII вв.) // Буддизм и государство на Дальнем Востоке. М.: Наука, 1987. С. 91-108.

15. Зельницкий А. Д. Правовой статус даосских и буддийских священнослужителей в имперском Китае (на материале кодексов Тан и Мин) // Общество и государство в Китае. 2011. T. 41, № 1. С. 364-368.

16. Зельницкий А. Д. Краткий очерк политики государства в области верований и ритуалов в Китае эпохи Тан (618-907) // Вестник Санкт-Петербургского университета. Сер. 17. Философия. Конфликтология. Культурология. Религиоведение. 2014. № 1. С. 65-75.

17. Полохало Ю. Н. Управление Китаем в эпоху Тан // Управленческое консультирование. 2005. № 4. С. 211-216.

18. Васильев Л. С.Проблемы генезиса китайского государства. М.: Наука, 1983. $327 \mathrm{c}$.

19. Янгутов Л. Е., Халтаева О. Р. Религиозные верования в политической культуре императорского Китая Улан-Удэ: Изд-во Бурят. гос. ун-та, 2016. 156 с.

20. Васильев Л. С. Культы, религии, традиции в Китае. М.: Наука, 1970. 484 с.

21. Комиссарова Т. Г. «Монах не должен быть почтительным к императору». Из буддийской полемики в Китае в IV-V вв. // Буддизм и государство на Дальнем Востоке. М.: Наука, 1987. С. 47-70.

22. Буддизм в социокультурных и политических процессах России, Внутренней и Восточной Азии: трансформации и перспективы. Улан-Удэ: Изд-во Бурят. гос. ун-та, 2016. $456 \mathrm{c.}$

23. Малявин В. В. Китайская цивилизация. М., 2000. 632 с.

24. Корнев В. И. Буддизм и общество в странах Южной и Юго-Восточной Азии. М.: Наука, 1987. 220 с.

25. Волков С. В. Служилые слои на традиционном Дальнем Востоке. М.: Восточная литература, 1999. $310 \mathrm{c.}$

26. Мартынов А. С. Основные категории классического конфуцианства // Классическое конфуцианство / пер. ст., коммент. А. Мартынова и И. Зограф: в 2 т. СПб.: Нева; М.: ОЛМА-ПРЕСС, 2000. Т. 1. С. 35-94.

27. Мазур Т. Г. Конфуцианство как идеология «служилого сословия» в сочинениях Хань Юя (768-824): автореф. ... дис. канд. филос. наук. Улан-Удэ: 2003. 21 с.

28. Кычанов Е. И. Основы средневекового китайского права (VII-XIII вв.). М.: Наука, 1986. 264 c. 
29. Илюшечкин В. П. Сословно-классовое общество в истории Китая (опыт системно-структурного анализа). М.: Наука, 1986. 397 с.

\section{MORE ON THE IMPACT OF BUDDHISM ON THE POLITICAL STRUCTURE OF SOCIETY IN TANG CHINA}

\section{Tatyana G. Mazur}

Cand. Sci., A/Prof.,

Institute for Mongolian, Buddhist and Tibetan Studies SB RAS

6 Sakhyanovoy St., Ulan-Ude 670047, Russia

E-mail: mtbi@yandex.ru

The article considers the impact of Buddhism on the political structure of society in Tang China (618-907). Based on the institutional and substantial approaches to the social structure of society, we have identified the main elements of the political structure: political institutions (the institution of the head of state, the institute of executive power, the institution of public service, the institute of law) and socio-political groups (emperor, the privileged estates, the unprivileged estates) of the Tangan society; analyzed the influence of Buddhism on them. It was concluded that the influence of Buddhism on the political structure of Tang China was inconsiderable. Buddhism did not have a significant impact on the political institutions of Chinese society; its appearance did not lead to the development of a new socio-political group and a new subject of law in political and legal relations. In the political structure of the Tang society Buddhism occupied a place in the Chinese traditional socio-political groups, which representatives were the carriers of its ideas. Keywords: Buddhism; religion; the Tang Era; society; political structure; political institution; institute of the head of state; institute of executive power; institute of public service; institute of law; socio-political group. 